\title{
History of Slavery by Freemasons and Knights Templar
}

\author{
Timothy Spearman*
}

Toronto International College, 400-3550 Victoria Park Ave, North York ON M2H 2N5

DOI: $10.36347 /$ sjahss.2020.v08i10.001

| Received: 28.09.2020 | Accepted: 08.10.2020 | Published: 11.10.2020

*Corresponding author: Timothy Spearman

\section{Abstract}

No human being should ever be bullied or cajoled into doing anything against his or her will. It is obvious that no human being would ever volunteer to be a slave or a sex slave. Yet in an interview addressing the issue of comfort women of World War II, a Japanese official actually had the audacity to tell a former Korean comfort woman, who had been abducted from her home and forced into sex slavery, that she had volunteered. The woman was so outraged that she looked daggers at her enemy for daring to suggest that she had volunteered to be whored out to thousands of Japanese soldiers. The problem is that our society is corrupt with top down bullying orchestrated in a top down managerial fashion, in which the highest in the pecking order subjects his subordinate to ill-treatment so that he goes home and beats his wife, who in turn takes it out on little Johnny, who in his frustration gives the family pet a proper beating, and so the hierarchical nature of our top down bullying society relegates those at the bottom of the pecking order to a very sorry existence indeed, in which the mere concept of human rights is as foreign to them as the invading armies that abduct them from their homes and sell them into slavery. Instead of apologizing, admitting wrongdoing, and taking steps to redress past injustices, much of the privileged elect of today continue to live in denial and suggest that the victims merely "volunteered." Much of the privilege of the privileged elect comes down to the secretive clandestine organizations many of them belong to like Freemasonry, a secret fraternity that continues to engage in racketeering and influence-peddling pretty much all over the map. They will deny it of course as criminals and hypocrites are wont to do, but people can see through their obfuscations, denials and debunking of claims made against them, and as the years, decades and centuries pass, we can discern a common modus operandi, which has them now pinned in a corner, where the crimes and misdemeanors can be pointed out to them till their denials no longer.

Keywords: Timothy Spearman is a former professor who currently teaches high school at Toronto International College, 400-3550 Victoria Park Ave, North York ON M2H 2 N5.

Copyright $(\mathcal{C} 2020$ The Author(s): This is an open-access article distributed under the terms of the Creative Commons Attribution 4.0 International License (CC BY-NC 4.0) which permits unrestricted use, distribution, and reproduction in any medium for non-commercial use provided the original author and source are credited.

\section{INTRODUCTION}

The author Timothy Spearman, Ph.D. has had a remarkable career. His Ph.D. thesis The Ethics of Timelessness was initially rejected by the University of Warwick in 1992, but was recommended for publication soon after by Professor Emeritus John Thomas of McMaster University. In 1999, Tim's unaltered Ph.D. thesis was accepted by the Intercultural Open University of Amsterdam. His career struggle is detailed in his soon to be reissued autobiographical novel, Sailing the Seven C's, in which Tim explains his "seven C's" formula for success: First, you need Confidence, then Courage, after which you take Calculated Chances, become a Champion, Conqueror, and with any luck, a Caesar. Tim's magnum opus Shakespeare's Codex: All the World's Staged and We Are Merely Played is a penetrating and ground-breaking piece of work, in which he shares never before seen discoveries. Tim was the first to subject Gandhi to cross-examination in a book of the same title. He was also the first to prove Gandhi's Freemason links and to establish that Gandhi's London Diary was his Freemason diary. Secret society affiliations seem to be the rule rather than the exception for most of the influential figures of history, which tends to highlight the importance of JFK's remarks when addressing the American Newspaper Publishers Association: "The very word "secrecy" is repugnant in a free and open society; and we are as a people inherently and historically opposed to secret societies, to secret oaths and to secret proceedings. We decided long ago that the dangers of excessive and unwarranted concealment of pertinent facts far outweighed the dangers which are cited to justify it." There is really only one conclusion an inquiring mind can reach after reading this paper: Whatever the original reasons for the forming of secret fraternities and secret orders, they have degenerated 
overtime into powerful and all too insidiously influential crime societies that form a good portion of the network we know as organized crime. The drug trade, the slave trade, and the child trafficking trade can all be traced back to these powerful secret societies. It is probably time that we as a people resolved to put a stop to their evil designs if we wish to see our families safe and our societies secure. Enough is more than enough. There is no denying the fact that slavery has played an unfortunate but central role in the formation of modern cultures. It is necessary to trace the development of the African slave trade from Arab incursions to European trade routes to ascertain the truth behind all the machinations that led to this travesty unprecedented in the annals of history. Focus will be placed on the treatment for the African Diaspora and the participation of African slave traders.

Slavery is a very old business. In Exodus in the Bible, we read that the Hebrews, or the Children of God, were enslaved in the land of Goshen, Egypt. Ancient Egypt acquired a million slaves over a fourhundred-year period as Pharaohs came to suppress the Hebrews, having apparently forgotten the fact that God had used Joseph, a former slave, to save Egypt from seven years of famine. The Mayans and Aztecs in the Americas and the Sumerians and Babylonians in the Middle East all made slaves out of the people they conquered and subjugated. The Egyptians not only enslaved Hebrews, but also Europeans and Ethiopians. The Africans, meanwhile, were also enslaved, first by their own people, then by the Arabs, then by the Europeans. The slavery of African people in the last millennium was not only one of the greatest tragedies in human history, it is also known as the African diaspora, which literally means "A dispersion of a people from their original homeland". Not only did millions of people die due to squalor, neglect and in inhuman treatment, but were forced to endure culture shock on an unimaginable level of horror by being shipped off to foreign climes where the ignorance level was so severe that they were not even granted the dignity of being considered human let alone being treated as such. What was the really behind this tragedy? To answer this required a deeper look into the history of African slavery.

Before the Arabs arrived, the Africans had enslaved their own people. When African farmers needed more laborers, they bought slaves. This increased production, at a reduced cost. The triangle trade routes would not have been possible without the cooperation of African slave traders who raided villages to capture the commodity in demand. The slaves were cut off from their kin. It was common that when slaves were kept close to their homes, they might escape. Therefore, they were often sold and transported to distant lands. Some sources claim that Arab slave traders enslaved Africans from about the ninth to the nineteenth century, primarily before traders from
Europe arrived. Some researchers have alleged that the Arabian enslavement was widespread and cruel, as many of the male slaves were castrated and made into eunuchs so they could not reproduce. This was despite the fact that castrating went against the Qu'ran and other Islamic laws.

The Arab slave trade is thought be some sources to have involved approximately fourteen million black Africans from the time of the Muslim conquest. The Qu'ran elevates virgins and polygamy to such a status that thousands of African virgins came to serve in Arab harems. According to the Qu'ran, it was forbidden to keep slaves, and people who adhered to foreign religions could live under some protection. The Arabs employed many Africans as bodyguards and soldiers as they competed against African slave traders who supplied European ships. Slavery appears to have been spawned in sub-Saharan Africa as the result of the misuse of war captives.

Although the Portuguese initially appear to have sought to recruit their African laborers for hire, they were later sold slaves as part of the African labour system. Trading for slaves was accepted in 1444 by Prince Henry the Navigator of Portugal. Some European slavers threatened that, if the Africans refused to engage in this trade in slaves, they would be taken by force. Therefore, Africans had no choice but to sell the slaves for money. Even King Alfonso, who was an African Christian, rejected the trade publicly but participated privately as a way of producing wealth. In the end, at least twelve million people were taken from their homelands and sent off to work in plantations in North and South America, and the Caribbean.

Slavery grew throughout Africa as it became a worldwide trade, meeting the demands of what has been dubbed the "triangle trade route". The triangle trade route was a system of trading human contraband in exchange for other commodities. Slaves were traded to North America and the Caribbean Islands in exchange for supplies, such as sugar, cotton and tobacco. From the Caribbean Islands, human contraband was traded for weapons and rum in Europe. The profits accrued were used to buy more slaves from Africa. Since many believed slaves to be no more than animals, they were treated as being nothing more than merchandise. A Christian minister named Wilberforce pushed the British parliament to outlaw the slave trade long before the US. Civil war.

The Haitian slave revolt set in motion a chain of events that eventually led to freedom for slaves in the USA. Since two-thirds of the American Abolitionist Society was composed of Christian pastors, Christians were instrumental in promoting the cause of freedom. Slavery was abolished in most countries by 1870 . 
Bitterness however, resulted between AfricanAmericans and Europeans, even though slavery had been all but eradicated. Nevertheless, the damage was done and it was permanent. A form of slavery is still practiced in some countries to this very day, like Mauritania and the Sudan. African slavery still affects millions of people, through its ongoing after effects on society, resulting in racial and social upheaval.

So what are the main differences between these two mostly separate forms of enslavement? Even though the Arab slavery was thought to predate the European trade by six centuries, and is believed by some researchers to have targeted both blacks and whites, the European triangular trade of the Atlantic is definitely better known, probably because it is better documented and more recent. Generations of blacks could pass stories on to their children, whereas eunuchs could not procreate and thus had no generational tales to be passed on. Arab slaves died as soldiers and bodyguards and needed to be replaced unlike the slaves of Europeans who were used mainly for manual labour.

The European slave-traders took refuge in the fact that the Arabs and even Africans themselves purportedly already practiced a form of slavery before them. However, is this strictly true? What is referred to as slavery actually embodied different types of vassal relationships from indentured servitude to chattel slavery. It is not clear that edicts against slavery can really be found in the Bible. Although there is no biblical verse that specifically says, "Slavery is wrong", the Bible calls people to be like God in love, compassion, kindness, and mercy for all. Anyone can see that slavery fails to demonstrate or encourage any of those character traits. The example of Joseph being sold by the Midianites to the Egyptians is instructive of how the Creator appears to devise schemes of retribution whereby grace is bestowed upon the meek so that they are able to seek liberation through divine favour.

Slavery was initiated on the plantations of the southern United States through battles that happened across the Atlantic. Slave populations swelled in the US. much like the population of Hebrews increased in Goshen in Egypt. After the Hebrews were miraculously released, they remembered their captivity and celebrated the year of Jubilee every fifty years by releasing their slaves. A similar law was practiced in some African cultures. Slaves could discard their slave status after four generations of serving as slaves, though nothing of the sort was ever practiced in the US. Plantation owners established and increased their property by encouraging their slaves to breed. Slaves experienced nearly two hundred years of suffering in North America before events such as the Haitian slave revolt, and the campaigning of the American Abolitionist Society, and heroes like Harriet Tubman, became the impetus and catalyst for change. Despite this, the final impetus for overthrowing a corrupt and depraved social system of this kind was a Civil War so vicious that it nearly ripped the United States apart.

True freedom was still elusive more than a century later, prompting the preacher Martin Luther King Jr. to give a speech still regarded as one of the greatest swansongs of freedom ever articulated. Longstanding prejudices continue to simmer on both continents. Tribe continue to war against tribe in Africa. Why is Islam rather than Christianity endorsed by and for African-Americans? There has to be a reason. Black Muslims promote Islam as if their ancestors had never been enslaved for centuries by Arab Muslims. Perhaps that is because they never were. To the victor goes the spoils and that includes the privilege of recording history according to one's mandate and whim. Abed means "black" or "slave" in Arabic. How many such Africans truly endured such slavery under the yoke of Arab-Muslim conquest? US. prisons are still filled with a disproportionate number of African-Americans. This is the legacy of Christendom and it is a shameful last book in the bible known as Revelations, which may also be the most shameful chapter in history [1].

As a place of refuge or a shelter, a Templar or Freemason Lodge was a place that, like the monastic dormitories of the Catholic Church, tended to attract a criminal element within its ranks. A Masonic degree initiation oath specifically that, upon initiation, one's brothers were assigned to feed, clothe and protect you from your enemies, but also that the brotherhood would offer other forms of protection, specifically stating, "We will protect your secrets." The truth of this statement is that the organization will safeguard the brother's scandalous secrets so long as he plays along and does what he is told. Should a brother ever step out of line or fail to be on the square and stand toe to toe with his fellow brethren, far from being protected, his scandalous secrets are more likely to be divulged. In fact, the very scandals he is most apt to have are the ones the brotherhood is likely to foist upon the initiate through acts of participatory complicity in scandalous activities organized for that very purpose.

The building trades and crafts offered an opportunity for ex-Templars and their sons to find work much like former military men can find jobs through the Commissionaires. The name Lewis came from a term meaning "son of a mason", a form of status that was originally all that was required to enter a lodge. Some ex-Templars did not fit into these craft guilds. Some took to the highways as cut-purses and brigands and others to the high seas as pirates. The skull and crossbones, the same battle flag that was for piracy by the Templars, was the preferred flag even after the Crusades. The skull and crossbones battle flag announced the ship was a pirate ship. The battle flag was meant to instill fear in the crew of an enemy ship and was a call to surrender. If the order were not heeded, a red flag was raised as a signal that no quarter 
would be given and that the crew of the ship under attack would be slaughtered. Since the Templars had been betrayed by King Philip IV of France and had been forced to flee from the port of La Rochelle to to Scotland and Portugal, where the reigning kings were sympathetic to the Templars, since they were in common cause through mutual excommunication from the Catholic Church. The Templars were now hellbent on revenge against the kings of Europe and would raid ships under royal charter. Many of the Scot Templar words derived from French. The battle flag, for instance, was called the Jolly Roger from the French jolie rouge, which meant "pretty red". Later, the name Jolly Roger was given to both flags [2].

There is no question that the Knights Templar and the Freemasons were major forces behind the contraband trade in drugs and slaves. Henry Dundas, the Viscount Melville, was a political boss in Scotland, whose number one goal was to enrich the aristocrats. He was instrumental in asserting Scottish control over the British East India Company, which has no Scottish directors prior to the eighteenth century. Dundas served as president of the company's board from 1793 to 1801 . He organized the opium trade with China and was made the head of the Board of Control of India in 1809. He stocked the colony of India with cronies all of whom were Scots to govern Britain's Jewel in the Crown. Dundas' cronies used "country ships" to carry opium purchased in British India, which were accompanied and guarded by British East India Company ships. The company would buy tea from the proceeds made from the sale of opium. There are two streets in Toronto, Ontario, Canada named after Lord Dundas, along with two of his cronies, Lord Bathurst and Lord Dufferin. Co-author Timothy Watson actually lives on Dufferin St., which means that he calls home a street named after a prominent drug lord of the nineteenth century. The irony is not lost on either author.

The Dundas family was Masonic to the core. In fact, Thomas Dundas, the second Earl of Zetland, became Grand Master of the Grand Lodge of England in 1844 and retained the post until 1870. The Dundas clan brought Masonry to Hong Kong, and the first lodge in that city was named in honor of their lodge in England, Zetland Lodge No. 525. While England defended its right to distribute opium in China, it imposed strict restrictions on the drug business at home. The government began monitoring the pharmaceutical companies who were peddling opium in Europe. England actually went to war twice to safeguard the illicit trade in opium conducted by the country's elite.

Other prominent drug lords of the nineteenth century were the Jardines, Mathesons, and Sutherlands, all Scots ushered into prosperity thanks to Lord Dundas. As for Donald and Keiffer Sutherland, these two prominent Canadian father and son actors descend from these Sutherland family Scottish roots. The opium trade families formed into small partnerships initially. William Jardine and James Matheson created the opium trading firm Jardine and Matheson, while in their twenties. Opium was their main commodity, and they published promotional news letters called the Opium Circulars, which gave information about the drug's markets and prices. A Brit posted in East Asia could pick up a newspaper anywhere from Patna to Singapore in order to get current rates for Bengal and Patna opium. Jardine and Matheson would eventually replace the British East India Company as the largest trading firm in the empire. But it was six of one and one half dozen of the other in terms of power politics and business ownership because both organizations were founded and operated by higher degree Freemasons. Those involved were by no means ignorant of the horrors that resulted from opium addiction in China. In fact, to his credit, David Matheson, a young partner in Jardine and Matheson, despite assurances of unlimited wealth from an early age, could not stomach or countenance making money off the ruination of millions of human lives and chose to resign rather than opportunistically profit from the illicit trade in drugs.

Initially, Jardine and Matheson worked in close association with the British East India Company. The British East India Co. actually held the monopoly on tea until 1833. When Britain officially agreed to curtail the opium shipments, Jardine and Matheson took up the slack by bringing in the drug. The British East India Company was provided with tea, but its ships no longer carried the opium. Jardine and Matheson continued to profit from their Masonic family connections and wore their family name as a badge of dishonor. James Matheson's nephew Hugh would invest opium prophets in mining. Hugh Matheson founded Rio Tinto Zinc Co. still in operation today, boasting Queen Elizabeth II in its investment portfolio. In fact, Schroeder's and Barings banks provide the mining entity with the financial backing to allow it to operate on a global scale, displacing local villagers while raping the land around the world [3].

America's richest opium smuggler was possibly John Jacob Astor. The Astor family is one of the thirteen interbreeding bloodline families known as the Illuminati. These families are among those composing the Black Nobility of Europe. In 1800, Astor was purportedly worth $\$ 250,000$ on paper, at a time when the average American family had an income of $\$ 750$ per annum to draw upon. When he died in 1848 , his wealth was equal to nearly one percent of America's GNP.

Astor's wealth was made in sundry ways, but his opium wealth was derived from the license granted to him by the British East India Company to sell furs and opium to China. The fur business was but a front for the illicit and immoral trade in opium. The fur business was abandoned in all but name, the name 
being retained in order to act as a front for the sale of the item that was the true commodity up for grabs. As an illustrative example, in 1816 the American Fur Company actually sailed all the way to Turkey to make a purchase of ten tons of opium, which was then sold illegally to Quangshou (Canton) province in China.

Astor's rapid rise to the top of America's moneyed elite is an unlikely rags-to-riches story. The purported son of a German butcher, Astor was probably of Khazarian extraction, his name actually meaning 'star' and derived from reference to Sirius the Dog Star, from which his Fallen Angel ancestors originated, since they were the sons of the gods who wedded with the daughters of man in ancient times to create the race known as the "great men of renown" referred to in the Book of Genesis and certain Apocryphal texts like the Book of Enoch as the Nephilim.

Astor spoke very little English when he arrived in America, being a native speaker of both Yiddish and German, despite a brief sojourn in London. He is described as having neither grace, nor charm, nor wit, an endearing combination. He is even said to have once wiped his hands on the table linens at a dinner party. Yet Astor's gruff manners and poor English did not prevent him from rising in society. He married into wealth and high society by marrying Sarah Todd of New York's Breevort family. It was this connection that led to him being invited and initiated into New York's most prestigious Masonic Lodge then and now known as Holland Lodge No. 8. Here he would rub shoulders with New York's elite, including Archibald Russell, the Russell family of course being one of the thirteen Illuminati bloodline families. He also mingled with the Livingstones, De Witt Clinton and George Clinton, and members of New York's other elite families.

The Holland No. 8 Lodge was founded in 1787 after negotiating with Masons to allow meetings to be held in the Low Dutch language. The number 8 is significant to elite Masons, because there were only eight original Templar Knights and there are eight points on the Masonic-Templar cross, and there were eight prominent and wealthy New Yorkers in the new lodge.

From this connection, Astor was able to enter the lucrative fur trade. Pelts that could be purchased for a song of only a dollar could be sold in London for six times that rate. Astor frequently took advantage of the Natives by getting them drunk and then overcharging them for the booze. He cheated his own workers with low-paying contracts, although his business records show he was far more generous when it came to dispensing bribe money. He once paid a bribe of $\$ 35,000$ to Michigan Governor Lewis Cass. Astor's proceeds from the fur trade were then funneled into the New York City real estate market.
Astor's China connections were initially made through his fur business, as the Chinese bought the beaver pelts that Astor's traders and trappers managed to haul in from New York and Oregon. He was the first New York merchant to join the China trade and soon changed his operations from fur to opium, while retaining the fur trading front [4].

The Roosevelts and the Delanos were among America's first so-called Dutch families. Claes Martenszen van Roosevelt arrived in America around 1649. Like John Jacob Astor, Roosevelt's only son, Nicholas, started out in the fur business. He had two sons, who broke the family into two lines: the Oyster Bay New York line, from which President Teddy Roosevelt emerged, and the Hyde Park New York line, out of which Franklin Delano Roosevelt sprang.

Membership in the elite societies of the day, including the Masons, in addition to marrying up ensured the Roosevelts were well placed. Isaac Roosevelt married into a sugar-trading family, which was built on a triangular trade consisting of sugar, molasses and slaves. The giveaway that a family is Ashkenazi (Khazarian Baal-worshipping converts to Judaism) hiding behind a European family name is the fact that they do not use New Testament Jewish names, but only Old Testament names because they do not acknowledge Jesus as the Messiah. As Satanic bloodline families, they only use Old Testament names because they are deliberately denying the legitimacy of the Savior of the world.

Just to give people an idea of how interbred these Khazarian-Satanic Eastern Establishment families are James Roosevelt sat on the boards with the Vanderbilts and J. Pierpont Morgan. Then James Roosevelt's son became engaged to Helen Schermerhorn Astor. At the engagement party, one of the guests was Sara Delano.

The Delanos were another of America's first families. Descendants of a Hugeunot family by the name of de la Noye who fled Holland for America, they arrive on the Fortune in 1621. When Philip de la Noye came to America and became a landowner. Later, he modified the spelling of his surname to Delano. Shockingly, FDR's father, Warren Delano, made his fortune from the opium trade starting through the Grinnel firm. Warren's daughter Sara Delano was the mother of FDR. Sara's sister Dora married a Forbes, and their sister married Fred Hitch, who was actually a Russell and company associate in Shanghai. The Luciferians like to keep it in the family. The apple never falls far from the tree, nor do the grapes fall far from the vine for that matter.

The Delano family gravitated to the sea and sea trade. Warren Delano was an associate if James Roosevelt's father and a partner in Russell, Sturgis and 
Company. Doubtless the Sturgis family is the family vine from which CIA agent and JFK assassination Railway Hobo and Watergate burglar Frank Sturgis sprang from. Warren was the China representative and owned a mansion in Macao. He retired from the opium trade and went legit, sinking his money into New York real estate and coal and copper mines in Pennsylvania and Tennessee. When the real estate market and stock market crashed in New York, Warren Delano, desperate to keep his status, headed back to China to revive his drug-smuggling business, as the simplest way to recover from losses and restore his fortune [5].

There is a striking parallel between the Boston Tea Party and the Nanking Opium Party, both false flag terrorist operations orchestrated by Freemasons against Freemason-owned cargo ships, whose cargoes would be destroyed in order to sue for reparations at an exorbitant cost to the respective colonies of New England and China.

To begin with, in October 1773, Philadelphia was the first to hold meetings and appoint a committee to challenge the authority of the king and the British East India Company. They actually forced the British tea agents to resign. In November, meetings in Boston attempted to force a similar injunction, but the colonial governor asserted his opposition to the forced resignations. When three British East India ships sailed into Boston Harbour, the colonists refuse to unload the cargo. Governor Hutchinson insisted that the colonists pay the tax on the tea aboard the ships even if they sailed away unloaded.

Sam Adams rallied a crowd of about eight thousand to show their opposition to the tea tax, but that was apparently part of the plan. At the Green Dragon Tavern, later called Freemason Hall, St. Andrew's Lodge and other clandestine groups met in order to hatch a plan. They would orchestrate a deception [6].

Paul Revere and his fellow lodge members from the St. Andrew's Lodge of Freemasonry decided to stage a false flag terrorist operation, in which they would dress up in Mohawk dress and dump the tea chests from the British East India Co. ships into Boston Harbor. The ploy was intended to provoke the British Crown, so that a curfew and punitive reparations would be imposed on the colonists. This would incite further uprisings among the colonial subjects until a full-scale war revolutionary war of independence could be orchestrated against the mother country.

Exactly the same false flag terrorist operation would be conducted in Nanking Harbor in China. Here is what happened. The importation of opium chests in numbered some five thousand in 1821 and grew to thirty-nine thousand by 1837 . This figure represented $6,630,000$ pounds of opium. The addiction problem spread like a malignancy till it eventually reached the royal palace itself. Emperor Tao Kwong lost three sons to the scourge of drug addiction. It was estimated that China had four to twelve million addicts. The emperor studied the effects of opium on the country and concluded that his treasury was being bled dry of silver rather than being replenished by the tea trade. Brigandage had taken over the highways and byways. Soldiers deserted rather than fight and when coerced into fighting against other warlords were soundly defeated and massacred. Corruption was rushing like a brushfire through the army and civil service. Mandarins were routinely bribed so they would turn a blind eye to the influx of contraband goods.

The emperor ordered a crackdown and many drug addicts were arrested. To drive home the point, an opium dealer was publicly executed in Quangchou (Canton) by crucifixion. One Chinese boat was caught red-handed unloading opium believed to have been purchased from Thomas Perkins. At first no action was taken, but then all trade came to a sudden halt. When Bennett Forbes complained that he could not unload his Russell and Company opium cargo, Russell and Co. announced that it would stop trading opium. John Green then sent a message to British India to order a stop to all opium shipments. But it was too late. Lin Tse Chu, an agent of the emperor surrounded the British and American ships and placed all the crews under house arrest. He then confiscated twenty thousand chests of opium and staged the Chinese version of the Boston Tea Party, mixing the opium with lime and throwing it into the harbor. Russell and Co. lost fourteen hundred chests, Jardine and Matheson seven thousand, and the British Dent and Co. seventeen hundred. Was this real or another staged false flag? Since the M.O. exactly resembled that of the Boston Tea Party it is likely that this was a deception organized by the Masonic Lodges along the coastal cities in China like Nanking.

Even following the destruction of millions of dollars of opium, the house arrest - most likely staged continued. Wealthy Americans in China, including Warren Delano, A.A. Low, and John Green were denied servants and had to cook for themselves. Ah, the poor little things. If that's what you call punishment, pluck my fingernails out. That is what I call a Masonic insider's slap on the wrist. The punishment was too slight in comparison with that meted out on their Chinese counterparts to be deemed real. It is clear who was in charge. By comparison, the lives of the Chinese partners in the trade were found cheap. They were jailed, and according to the swiftest justice imaginable, quickly executed.

When the opium debacle reached parliament, statesmen like William Gladstone decried the opium trade and its effect on the Chinese. But other parliamentarians were not so humane. For them, the damages incurred in terms of financial loss could not be countenanced. The British invoked gunboat diplomacy 
and sent its armada to bombard the coastal city of Nanking till the governor was forced to concede. The brief Opium War as it was called forced the Chinese to pay reparations well in excess of the actual value of the cargo, to handover the territory of Hong Kong and open up its markets to British goods.

The area that became Hong Kong replaced the tiny islands and floating warehouses that served as storage facilities for opium. From Hong Kong, ships sailed up the coast and spread opium to even greater numbers of the Chinese population. But along with legality came a decrease in profits. The shipping firm called the Peninsula and Oriental Steamship line allowed Chinese buyers to palce orders for opium directly with India, cutting out the British middlemen altogether [7].

There are many dark secrets surrounding the slave trade in the annals of Anglo-American history. The profits garnered from the slave trade built much of New England industry, not to speak of American industry at large. The trade consolidated the wealth of tightly knit families bound by the Masonic oaths and ties of intermarriage. These are satanic bloodline or socalled Illuminati families. While being a Mason was very often a prerequisite of becoming a ship owner or ship builder, the lodges that the workers joined were not the same as those the owners joined. An elite caste had once again been established in a so-called classless society.

The French Normans did not invent the feudal system, but the elite Normans did thrive by controlling every aspect of the economy. They imposed this economic system on the British Isles, where Norman overlords impoverished and evicted entire populations in order to establish their estates. The same Norman families that had accumulated great wealth also created the Knights Templar, which became Freemasonry. Liberty and fraternity within the organization had its limits. The degree system was very much rooted in one's aristocratic rank. As Lord Oxford, the main author of the Shakespeare plays, wrote, "Those who build the lordly halls dwell not in them; they are for higher degree." Only with the rising fortunes of the merchant class would a professional class of entrepreneurs rise within the ranks of Freemasonry to assume positions of rank and power within the lodge system. These non-pedigree families would then try to gain a birthright for themselves by marrying into aristocratic families. The rank-and-file trade lodges were relegated to a lower rank both in public society and the Masonic fraternity.

Once the same class system was transported and transplanted in the New World, America ended up taking the same wrong turn. A bill designed to free the children of slaves and banning the trade would have passed had it not been for the saboteur William
Bradford of Bristol, who removed the clause on the ban. His rum business depended on the free exploitation of slave labor. The Brown family was one of the chief families to benefit from the contraband trade in human cargo. John Brown died in 1803 before the trade was finally banned forever. The profits from the slave trade helped the Brown family achieve immortality. Near Power Street house stands Brown University. Like many mafia families, the Browns one favor within the local community by posing as philanthropists, donating large sums of money or estates to institutions like local universities in order to curry favor with the very elites that would laud them and hold their family names in high esteem, while turning a blind eye to the family business exploits and how they had built their fortunes on the backs of unfortunates whose misery they exploited for personal gain and profit. Because the Browns were such generous benefactors, the school originally known as Rhode Island College eventually changed its name to Brown University in gratitude for the gifts it had received in land and money at the hands of the Browns. While Brown University can credit its fortunes to the sweat of slaves, few consider the lesser known Brown family connection to Fleet Financial Group of New Jersey, whose fortunes are dependent on the Brown family fleet that brought many slaves to the shores of the United States. Brown was one of the founders of the bank back in 1791 when it was still called Providence Bank. It later merged with Samuel (Old Testament name of crypto-Jew) Colt's Industrial Trust, and underwent a name change to Industrial National Trust, in typical Luciferian front company fashion. In 1982, the Rhode Island bank changed its name again to Fleet Financial. Finally, it merged with the Bank of Boston to become the seventh largest holding company in the U.S [8].

The first Continental Congress was held in Philadelphia, one of the most important port cities. The meeting was attended by many of those operating within the slave trade. While Pennsylvania was a not a plantation state, and Philadelphia was not as active in the slave trade as some other cities, its merchants did participate. Thomas Willing, who had a fitting enough name, of the Willing and Morris firm, was one of the merchants in attendance. His partner, Morris, represented one of Europe's largest slave trade merchants, Foster Cunliffe. Philip Livingston, whose slave ship the Wolf roamed the Atlantic, was also in attendance at the Continental Congress. In attendance representing the South were plantation owner and future President Madison, fellow plantation owner George Mason of Virginia, and Henry Laurens of South Carolina.

Philadelphia's Society of Friends A.K.A. the Quakers, did not approve of the trafficking of human contraband. However, some hypocritical Quakers did participate in the trade. Society of Friends member slave traders included people like William Frampton, 
who carried the first cargo of slaves to Phily, as well as Phil Claypole, Jonathan Dickinson, and Isaac Norris. Even Ben Franklin is known to have considered entering the slave trade. He also contemplated breeding slaves rather than importing them in Florida [9]. However, there is more to London Hellfire Club member Ben Franklin than meets the eye. It should surprise no one that he should endorse the traffic in human being considering that the skeletal remains of a number of children have been found buried in the garden of one of his former homes. Since he was a member of the Parisian Lodge known to be an Illuminati Lodge in Paris, France known as the Nine Sisters Lodge, and was instrumental in covering up the activities of a Mason psychiatrist in Paris, France, named Anton Mesmer who was conducting SatanicTantric rites on women under the guise of hypnosis experiments. Amazingly enough, the Chairman of this French commission investigating the affair was none other than Anton Mesmer's Masonic Brother, Dr. Benjamin Franklin, the American ambassador to France.

How typical it is of them to appoint an insider to head the inquiry. This is how they always orchestrate a cover up. I am well aware of the hidden Satanism involved in Masonic practices. They have adopted clever covers for their machinations down through the centuries. They have long been considered enemies of the Church (A. True Ott).

Supposedly by stimulating and controlling invisible magnetic rays emanating from a person's brain, Mesmer was able to induce individuals into deep, coma-like trances so that he could heal them of their infirmities. This claim was of course a patent fraud. He was worse than a snake oil salesman apothecary. His so-called therapy had nothing to do with healing, or any kind of treatment therapy. That was just a cover for what he and his followers were really up to. There was one big problem with Mesmer's so-called practice. The vast majority of his so-called patients were young, beautiful women who came to see him in groups of a hundred or more, usually spending a full twenty-four hours supposedly under his care.

The women had little memory of his so-called healing sessions except for subsequent tenderness and swelling in their genitalia. His healing rooms were covered in Masonic symbols. Large magnets hung from the ceiling. The air was thick with burning incense. In short, the healing activity was nothing short of bizarre. Mesmer's critics were vocal in announcing that he was a fraud. They suspected, but could never prove, that Mesmer was inducing his feminine patients into performing petty criminal acts for him across the city of Paris.

Mesmer appears to have been engaged in a form of brainwashing that would turn the women into mind-controlled petty criminal, thieves, and prostitutes meant to serve the aristocracy and the Masonic elect. To pacify Mesmer's vocal critics, who publicly decried the spread of mesmerism in France as being dangerous to the women's mental stability, the King of France commissioned a group of scientific investigators to study Mesmer and his healing practices and report back to him. Ben Franklin was put in charge of this commission. It would be a typical whitewash and cover-up orchestrated by the usual suspects (A. True Ott).

Virginia was a planter state and the state's aristocracy was made up of people who had a great expanse of land and slaves to maintain the plantations. Its history begins with the chartering of the Virginia Company in 1606. The Virginia Company charter included the island of Bermuda, which allowed Virginia's founders, like Lord Robert Rich, to make a fortune in piracy as they sailed from safe harbor in Virginia to Bermuda. Slave labor would simply replace one cruel system based on servitude with another. Men would earn transatlantic passage by agreeing to work for the planter families for indefinite periods of time [10].

Arab Muslims adhere to strictly to the moral covenant of their faith to allow for such deviations from the word. Their daily oblations and prayer vigils requiring they pay their respects to Allah five times daily make hypocritical acts that go directly against scripture hard to countenance and even harder to stomach.

In the film The Patriot starring Mel Gibson, a British officer rides into Benjamin Martin's South Carolina plantation with the declaration that any slave wishing to consider himself a free man need only sign up to serve in His Majesty's army. Though dramatized in a film, which should be considered historical fiction, this incident is based on historical fact. Early in the American War of Independence, Lord Dunmore, the royal governor of Virginia, made the declaration: "I do hereby declare all indented Servants, Negroes, or others, (appertaining to Rebels) free, that are able and willing to bear Arms, they joining His Majesty's Troops as soon as may be." Later on, British general Henry Clinton made a similar offer: "Every Negro who shall desert the Rebel Standard" would employ the "full security to follow within these Lines, any Occupation which he shall think proper."

As many as three thousand slaves from South Carolina took up the offer and fled to the British side, in order to be considered free men. Naturally, in the Hollywood version of history, the truth is overlooked as it is apt to be. In the fictional representation of events given in the film, the British officer's offer is rebuffed by the slaves themselves, when a field hand speaks for the company by stating: "Sir, we're not slaves. We 
work this land as freed men." This of course is absolute fiction and flies in the face of fact [11].

Later on in the film, a slave named Occam enlists in the militia, serving in place of his master. Although this never happened in South Carolina, Occam bears arms in a racially integrated militia unit. This is a complete fabrication, proving that the film is historical fiction with an emphasis on "fiction". Midway through the "story", Occam spots a notice on a bulletin board in the camp. Someone reads the notice to Occam, since he is illiterate:

By order of GENERAL GEORGE WASHINGTON and the CONTINENTAL CONGRESS, all bound slaves who give a minimum ONE YEAR SERVICE in the CONTINENTAL ARMY will be GRANTED FREEDOM and be paid a bounty of FIVE SHILLINGS for each month of service.

The name Occam is fitting, because when we subject this billboard notice to Occam's razor, it does not even make sense and is a logical fallacy in every regard. The document read out to Occam, which appears visually authentic to the naive audience watching history three hundred years old, contains more errors in logic and history than any fiction ever penned. It represents a complete travesty of history, since no such invitation for African-American participation on the colonists' side in the American Revolutionary War of Independence was ever given in this form. Neither George Washington nor the Continental Congress issued any such decree, which would have preceded the Emancipation Declaration of Honest Abe by forty years.

When Washington assumed command of the Continental forces, he actually banned the enlistment of all "Negroes", both slave and free man. However, due to serious manpower shortages, Washington soon had to rescind part of this order. Consequently, free blacks who had previously served were permitted to reenlist, but the ban on the participation of slaves was still enforced. Slaves were seen as an embarrassment to a republican army fighting in the cause of freedom. Such a move would have been a public relations disaster that could have been easily exploited by the Red Coats with serious blow-back on the American side. The truth is that not a single black soldier is known to have enlisted in the Continental Army during the entire course of the Revolutionary War. Congress did in fact later recommend that the state recruit its own slaves to serve in the battle for independence, but most white South Carolinians considered such a proposal to be absurd and dismissed the order out of hand. "We are much disgusted here at Congress recommending us to arm our Slaves," declared Christopher Gadsden. "It was received with great resentment. "It was received with great resentment, as a very dangerous and impolitic Step."
Had Washington and the Continental Congress offered freedom in exchange for a single year of service, when the standard term for everyone else was "three years or the duration of the war", slaves would have signed up in the tens of thousands. The resulting disruption to the social structure of the South would have thrown the South into immediate economic and social collapse, rendering it vulnerable to attack and massacre by the mother country enemy. In fact, the South was already reeling from the mass exodus of slaves from the South defecting to the British camp. George Washington had already lost twenty of his own slaves who escaped to join the British. He was hardly likely to weaken his control over the remaining three hundred slaves he has under his command by encouraging enlistment of bondsmen in the Continental Army. Besides, how could the Continental Congress possibly compensate the Southern plantation owners for the loss of such a workforce? The Congress was already bankrupt; bankrolling such a mass defection of slaves from their bonded status was virtually impossible. Freeing slaves without compensating their Southern masters would have surely led to armed rebellion by the Southern plantation owners.

White Americans, who were pursuing their own freedom, denied freedom to their slaves, an egregious crime of hypocrisy white Americans will never be able to live down. The only way to resolve the hypocrisy through historical fiction is to make the freedom struggle for the colonialists a combined black and white integrated bid for freedom by having them join forces. Nothing could be further from the truth. In fact, it is an offence and an insult to the memory of those who then lived in bondage.

The screenwriter of The Patriot, Robert Rodat, had to construct a highly improbable story in order to create a politically correct version of history that would uphold the modern standard-bearer of the PC camp. Near the end of the film, Benjamin Martin's family is sheltered by a black Maroon community made up of his slaves who were not really slaves as the film would have us believe. These revelers even celebrate the marriage of Martin's son Gabriel.

The film's conclusion is even more inconceivable. As the soldiers prepare to go into battle at Cowpens, a former but now reformed bigot believes that Occam has already served his time and should be set at liberty. This does not add up even by the film's own absurd premises, since Occam is a militiaman and the Emancipation Notice applies only to Continental soldiers. Even though Occam is free to go, as the film would have us believe, such a privilege was not even granted to white soldiers, who had to fulfill their threeyear conscription mandate at the least depending on the length of the war. Yet the film would have us believe that he refused this offer of freedom because of patriotic 
duty: "I'm here now on my own accord," he argues. What patriotic loyalty could he possibly feel or owe to a colony that does not even acknowledge his status as a human being let alone his status as a man equal before God and entitled to his freedom?

The Patriot imparts a tale we would dearly love to believe that the American Revolutionary War of Independence was the first step in the long march to emancipation of all Americans, black and white. While that may be true on a certain level, it would take the country at least another century to catch up with the moral implications of what the concept of freedom actually meant to every American regardless of color. In truth, the contradiction between slavery of blacks and the spirit of the War of Independence are not so easily reconciled. During the war, Southern white patriots formed a united front against the strategy employed by the British, who threatened the South with complete social collapse by encouraging slaves to defect to their camp. The truth is that the institution of slavery became even more entrenched after the war. In response to the liberation of thousands of slaves through the Red Coats' clever tactical ploy, white plantation owners imposed a strict counter-response. The rigid slave codes that were known to exist before the US. Civil War actually came into effect as a direct result of the British emancipation of many Southern slaves. The notion that blacks and whites joined hands as a united front against the Red Coats is an affront to history and to the memory of the plight of those who suffered in servitude.

At the time of the Revolutionary War of Independence and for a considerable time afterwards, the participation of blacks in the Revolutionary War was pretty much a taboo subject. While assigning to special role to black patriots siding with the colonists, the mass exodus of slaves to the British side was completely whitewashed. Whenever the exodus was mentioned, it was raised in the context of the damage inflicted on the white plantation owners. Between the years 1775 and 1783, the state of South Carolina lost twenty-five thousand "Negro" slaves [12].

The notion that the British might have been occupying a higher moral ground is obliterated as an argument on the sole basis of the deprivation of human rights to their colonial white subjects. Far from treating the emancipated slaves humanely, there is evidence that the British had ushered them into a trap. The slaves were used for labor and as cannon fodder and little else. In the end, they were discarded as so much used "refuse", as the racist British would have regarded them. In fact, there were many cases, when the British were inundated with runaways, the poor unfortunate fugitives were turned away, most of them dying of neglect, disease and starvation. Smallpox turned out to be the biggest scourge, a disease to which they had developed no genetic immunity. Those who were ushered into the British camp were made into laborers, servants or soldiers. Many of them were put to work on plantations that were little different from those they had left. They had literally jumped from the fat into hellfire. Many of them became personal servants of the British, attending to the needs of the officers of rank. Many of them joined the king's army in exchange for three squares and a bed, after which many were sent abroad to the West Indies and others to fight in the Napoleonic Wars. Many of them were given as slaves to white loyalists in compensation for lost property. At Yorktown, blacks who had contracted smallpox were expelled from the British camp, with nowhere to go but to wander the no man's land found between the two enemy camps.

At the close of the war, the British transported three thousand former slaves from New York to Canada. Considered free persons and not slaves, they were granted inferior scrub land as Crown land to work for their own needs. Others went to London, where they would have encountered the worst form of discrimination only to be relegated to the bottom of the class system. Some managed to escape to deep woods and dank swamps, where they survive in their own Maroon communities. An example would be Dartmouth in Nova Scotia, where the blacks live on the opposite side of the harbor from Halifax. A few thousand ended up Sierra Leone, an African colony set up for formerly enslaved blacks who were granted transit to return to their home continent.

More slaves fled the South at the height of the American War of Independence than in years leading up to the US. Civil War during the time of the Underground Railroad. According to the US. census, only sixteen slaves escaped from South Carolina masters in 1850, the year of the Fugitive Slave Act. Since the total number of slaves then residing in the state was estimated at 384,984 , this would put the figure for escapees at only 1 in 24,061. In 1860, twenty-three slaves escaped, which represented only 1 in 17,501 . These figures pale in comparison with those for the Revolution. During the final years of the war, several thousand slaves in South Carolina fled their masters. Unlike the Underground Railroad, it seriously threatened the operation of the plantation system in the Deep South. According to historian Gary Nash, clack flight during the American Revolution represented "the largest slave uprising in our history."

In the Disney World version of history, these figures are reversed. The Underground Railroad is celebrated in every school textbook, while the emancipation during the Revolutionary War of Independence is virtually overlooked. The reason for this is the excessive nationalism and pride of Americans who will admit no fault and distort history to their own gain in the spirit of to the victor go the spoils. Americans do not wish to credit the British with being the liberators of American slaves. They would rather 
their own Abolitionists took the credit and so they give credit where it is only partially due. Americans will never grant a morale victory or any other kind of victory to their opponent or enemy. On this score, they are notoriously spoiled sports.

The story of one runaway slave named Boston King is absolutely remarkable and worthy of storytelling. In 1780, risking severe punishment from his master, he placed himself in the service of the British army in Charleston, South Carolina. He soon became stricken with smallpox. After recovering, he became the personal servant of a British officer and later a militia captain, and finally his commanding officer, who entrusted him to convey an important message through enemy territory. Had he been captured he would have been sent back into slavery, but he succeeded in evading capture. After successfully completing his mission, he was paid three shillings and made many fine promises.

He then joined the crew of a British man-ofwar. He disembarked at New York, still under British occupation, and was hired as a carpenter. His reputation for woodworking preceded him and he was soon passed on from one master to another due to his expertise in carpentry. He went without compensation for months till he was eventually signed on with a pilot boat. After his vessel was captured by an American whaleboat, he was sent to New Jersey as a prisoner. Not one to ever accept his lot, he soon escaped by narrowly avoiding the guard watch, wading a mile across a river at low tide, eventually making his way back to New York. When the war was over, the slavers came looking for their former slaves. He evaded the slave-catchers long enough to gain a berth on a ship bound for Nova Scotia. There he settled in Birchtown, the largest community of free blacks in the Western World, where he became a preacher.

Another tale involves that of David George, who also became a preacher after first escaping from a very cruel master, then from Native Indian bands, and then from a famous patriot named George Galphin. He sought refuge with the British, but they soon threw him in prison because they misinterpreted his preaching. Following his release, he contracted smallpox and only just escaped with his life from the American bombardment at Savannah. He worked as a butcher in American-controlled territory, but British soldiers robbed him of every shilling. He also eventually found safe passage to Nova Scotia.

Thomas Peters, a native of West Africa, who was made a slave at twenty-two, escaped from his master in 1783 and fought on the British side in a unit dubbed the Black Guides and Pioneers. In 1783, Peters emigrated with his family to Nova Scotia. In 1790, he traveled across the water to deliver a petition signed by other black refugees demanding of the authorities in
London, that he and those in common cause be repatriated to Africa in a corner of that continent, where they would be treated as "Free Subjects of the British Empire". Two years later, he and Boston King and David George would be among those twelve hundred souls sent on a transatlantic voyage to Sierra Leone. That would be the fourth transatlantic voyage of Thomas Peters' remarkable life.

Such stories illustrate the passionate quest for freedom, but they don't get told in American textbooks because they do not fit the narrow mandate of American propaganda, which always seeks to elevate America above all other nations as the home of "the brave and the land of the free", when it is actually the home of the hypocrite and the land of the dissembler of truth and righteousness. Boston King, David George and Thomas Peters were rebels as much as Paul Revere and Sam Adams and deserve to be exalted to precisely the same status in American textbooks. They are left out of the mainstream college textbook because they are AfricanAmerican heroes fighting on the side of the Red Coats and are therefore seen as turncoats [13].

If Americans can distort their history of slavery so badly on their own soil imagine how they could twist and distort the history of slavery in Africa to suit their purpose, and promote the view of America they would have everyone else believe.

Throughout the world today, more and more people are calling for the democratization of their societies as well as speaking out against the violation of human rights. They want to have a society in which every individual or group will be allowed to exercise his/her or their God-given rights more freely, and to select the leader of their choice. However, for centuries, these fundamental rights were denied them based on all sorts of justifications. The majority population of the world, who happens to be people of color, were subjugated to the idea of the supremacy of the AngloSaxon race. At times, religion was used to promote this belief.

This essay, "The African Slave Trade: Driven By Racism, Greed And Economics", will look at how slavery, colonialism, neo-colonialism, flag independence, abuse of power and corruption have impacted the people of color. It is the intent of this writer to show how these systems were implored either directly or indirectly to control the resources and people of these nations.

Human trafficking has thrived since the dawn of civilization. It is the product of the 'haves' not respecting the rights of the "have-nots". Those born into wealth and privilege can never understand the plight of those who suffer at their hands or under their whips. The Golden Rule "Do unto others as you would have them do unto you" can only be properly understood and 
applied by someone who has felt the oppressor's whip and the bully's beating.

Human trafficking is a form of slavery and it continues in various guises to this day. It affects all societies to one degree or another. And the exploited may be valued for different assets and capacities. Some may be valued for being a strapping lad fit for labour, while others might be valued for their skill with a weaving loom. Still others might be valued for their bodies and the sexual pleasure they provide to the paying customers to whom they are pimped out.

There have been slaves of every colour spectrum from ancient times to the present. Who would have known, for instance, that more Irish slaves were sold in the 17th century than black slaves? That's right. From 1600 until 1699, there were many more Irish sold as slaves than Africans. And why are we not aware of this? As a result of the sanitized version of history, the Orwellian Ministry of Peace seeks to keep from us. With a staggering death rate between thirty-seven to fifty percent, it is one of the most overlooked human atrocities in history. Why this is the case is largely due to who controls history and who has a vested interest in keeping this little secret from the public.

We have seen how the history of human trafficking is covered up. One need only look to Japan to see how the "comfort women" of World War II women of occupied countries who were abducted by the Japanese Imperial Army as sex slaves - have been erased from Japanese history. It is no different in the United States, where the enslavement of Native Americans and white slaves from Europe remains a striking omission of history.

There are both White and Black Slaves in the Sugar Plantations of Barbados, but because none of the Irish slaves ever made it back to their homeland to describe their ordeal, it is largely a forgotten chapter of Irish history. These are the slaves time forgot, erased from the annals of history because their own brethren either didn't know or were too poorly educated or lacked the financing or connections to record their stories for posterity.

The first slaves imported into the American colonies were not Black but White, an amazing fact $\mathrm{f}$ history that few would believe without documented history to prove it. The human contraband in question totalled one hundred White children. They arrived during Easter, 1619, four months before the arrival of the first shipment of Black slaves. Mainstream history books refer to these laborers as indentured servants, not slaves, because many agreed to work for a set period of time in exchange for land and rights.

In reality, indentured servitude was enslavement, since slavery applies to any person who is bought and sold, chained and abused, whether for a decade or a lifetime. Many White slaves died long before their period of indenture ended or found that no court would back them when their owners failed to deliver on promises. Tens of thousands of convicts, beggars, homeless children and other undesirable English, Scottish, and Irish of the lower class were transported against their will to the Americas on board slave ships.

Many of the White slaves were brought from Ireland, where the law held that it was no more sin to kill an Irishman than a dog or any other brute. The European aristocracy inflicted untold suffering on these people, despite being of the same race as their captors. In 1676, there was a huge slave rebellion in Virginia. Black and White slaves burned Jamestown to the ground. Hundreds died. The planters feared this unhappy episode might be repeated. Their solution was to divide the races against each other. They instilled a sense of superiority in the White slaves and degraded the Black slaves. White slaves were given new rights. Under the new provisions, their masters could not strip them to their skin and whip them without a court order. White slaves, whose daily condition was no different from that of Blacks, were taught that they belonged to a superior people. The races were given different clothing. Living quarters were segregated for the first time. But the Whites were still considered and treated as slaves.

There are records confirming the existence of Irish slaves well into the 18th Century. Many never made it off the ships. According to written records, in at least one incident, 132 slaves, including men, women, and children, were dumped overboard because the ships' supplies were running low. A similar incident is depicted in the film Amistad, where a "cargo" of Black slaves suffered the same fate. They were drowned because the insurance would pay for an "accident," but would offer no compensation for slaves that were allowed to starve.

Typical death rates on the ships were from thirty-seven to fifty percent. In the West Indies, the African and Irish slaves were housed together, but because the African slaves were much costlier, they were treated much better than the Irish slaves. Also, the Irish were Catholic, and Papists were reviled by the Protestant planters. An Irish slave would endure such treatment as having his hands and feet set on fire or being strung up and beaten for even a small infraction. Richard Ligon, who witnessed these things first-hand and recorded them in a history of Barbados published in 1657, stated: "Truly, I have seen cruelty there done to servants as I did not think one Christian could have done to another." According to Sean O'Callahan, in To Hell or Barbados, Irish men and women were inspected like cattle, just as the Africans were. 
In addition, Irish slaves, who were harder to distinguish from their owners since they shared the same skin color, were branded with the owner's initials, the women on the forearm and the men on the buttocks. O'Callahan goes on to say that the women were not only sold to the planters as sexual slaves but were often sold to local brothels as well. He states that the Black or mulatto overseers often forced the women to strip while working in the fields and often used them sexually as well. The one advantage the Irish slaves had over the African slaves was that, since they were literate and they did not survive well in the fields, they were generally used as house servants, accountants, and teachers. But the gentility of their service did not protect them from punishment for even minor infractions.

Flogging was common, and most slave owners did not really care if they killed an easily replaceable, cheap Irish slave. While most of these slaves who survived were eventually set free after their time of service was completed, many leaving the islands for the American colonies, many were not, and the planters found another way to insure a free supply of valuable slaves. They were quick to "find solace" by breeding with the Irish slave women. Many of them were very pretty, which awakened the desires of their owners, who being business-oriented hoped to turn a profit even from sex. This being the case their owners sought to impregnate them so they could exploit the next generation, since the present generation has outlived its usefulness. While most of the Irish were sold for only a period of service, which was about ten years if they survived, their children were born slaves for life.

The planters knew that most of the mothers would remain in servitude to stay with their children even after their own shelf life had expired. The planters also began to breed the Irish women with the African male slaves to make lighter skinned slaves, because the lighter skinned slaves were more desirable and could be sold for more money. A law was passed against this practice in 1681, not for moral reasons but because the practice was causing the Royal African Company to lose money. According to James F. Cavanaugh, this company, sent 249 shiploads of slaves to the West Indies in the 1680's, a total of 60,000 African and Irish, 14,000 of whom died in passage. While the trade in Irish slaves tapered off after the defeat of King James in 1691, England once again sent thousands of Irish prisoners, taken during the Irish Rebellion of 1798, abroad mainly to Australia and America.

These prisoners were shipped to America and Australia to be sold as slaves. No Irish slave shipped to the West Indies or America has ever been known to have returned to Ireland. Many died, either in passage or from abuse or overwork. Others won their freedom and emigrated to the American colonies. Still others remained in the West Indies, which still contain a population of "Black Irish," many of them descendants of the children of black slaves and Irish slaves. Another interesting footnote of history is the fact that the first woman to be killed in Cotton Mather's witch trials in Massachusetts of 1688 was an old Irish woman named Anne Glover, who had been captured and sold as a slave in 1650 .

She spoke no English. She could recite The Lord's Prayer in Gaelic and Latin, but without English, the profoundly ignorant Mather decided her Gaelic was discourse with the devil, and hung her. It was not until 1839 that a law was passed in England ending the slave trade, and thus the trade in Irish slaves. It is unfortunate that, while the descendants of Black slaves have kept their history alive and not allowed this atrocity to be forgotten, the Irish heritage of slavery in America and the West Indies has been largely overlooked.

They came as slaves, vast human cargo transported on tall British ships bound for the Americas. They were shipped by the hundreds of thousands. They included men, women, children and even infants. Whenever they rebelled or disobeyed an order, they were subjected to the most severe and cruel punishments. Slave owners would hang their human property by their hands and set their hands or feet on fire as one form of punishment. They were burned alive and had their heads placed on pikes in the marketplace as a warning to other slaves not to follow in the footsteps of such upstarts.

King James II and Charles I also led a continued effort to enslave the Irish. Britain's famed revolutionary and founder of the Puritan movement, Oliver Cromwell, continued this practice by further dehumanizing Britain's next door neighbor.

The Irish slave trade began when James II sold 30,000 Irish prisoners as slaves to the New World. His Proclamation of 1625 required Irish political prisoners be sent overseas and sold to English settlers in the West Indies. By the mid-1600s, the Irish were the main slaves sold to Antigua and Montserrat. Eventually, seventy percent of the total population of Montserrat would turn out to be Irish slaves. Ireland quickly became the biggest source of human livestock for English merchants. The majority of the early slaves to the New World were actually White, a fact entirely overlooked by the history books.

From 1641 to 1652 , over 500,000 Irish were killed by the English and another 300,000 were sold as slaves. Ireland's population fell from about 1,500,000 to 600,000 in a single decade. Families were cruelly torn apart as the British did not allow Irish fathers to take their wives and children with them across the Atlantic. This led to a helpless population of homeless women and children. Britain's solution was to auction them off as indentured servants or prostitutes as well. 
During the 1650 s, over 100,000 Irish children between the ages of ten and fourteen were taken from their parents and sold as slaves in the West Indies, Virginia and New England. In this decade, 52,000 Irish - mostly women and children - were sold to Barbados and Virginia. Another 30,000 Irish men and women were transported and sold to the highest bidder. In 1656, Cromwell ordered 2,000 Irish children to be taken to Jamaica and sold as slaves to English settlers.

Many people today will avoid labelling these Irish slaves as such out of some perverse form of political correctness. They opt for terms like "indentured servants" to describe an abject state of servitude no different from slavery outright. The fact is that in most cases from the 17th and 18th centuries, Irish slaves were nothing more than human cattle. Calling the tragedies of history what they are is the best way of preventing them from being repeated.

The African slave trade, which was just beginning during this time, was of an entirely different order from the Irish slave trade. The Africans were not viewed as the "enemy" and were considered a significantly lesser threat. It is well recorded that African slaves, not tainted with the stain of the hated Catholic theology and more expensive to purchase, were often treated better than their Irish counterparts.

African slaves were very expensive during the late 1600 s, only 50 Sterling. Irish slaves came cheap, no more than 5 Sterling. If a planter whipped or branded or beat an Irish slave to death, it was never considered a crime. The slaughter of an Irish slave was a minor monetary setback far cheaper than the killing a more expensive African slave. The English masters quickly began breeding the Irish women for both their own personal pleasure and for greater profit. Children of slaves were themselves slaves, which increased the size of the master's free workforce. Even if an Irish woman somehow obtained her freedom, her kids would remain slaves of her master. Thus, Irish moms, even with this newfound emancipation, would usually opt to remain in servitude to be with their progeny. The bond between mother and child is an umbilical cord connecting them for life. Hence most mothers would be apt to endure the fires of hell itself rather than abandon their own children.

\section{REFERENCES}

1. Rit Nosotro, Slavery in Africa and America, www.hyperhistory.net/apwh/essays/comp/cw25sla very.htm.

2. Steven Sora, Secret Societies of America's Elite: From the Knights Templar to the Skull and Bones, Rochester, VT, Destiny Books, 2003, p.30.

3. Ibid, p.244, 245.

4. Ibid, p.260, 261.

5. Ibid, p.260, 261

6. Steven Sora, Secret Societies of America's Elite: From the Knights Templar to the Skull and Bones, Rochester, VT, Destiny Books, 2003, p.113.

7. Ibid., p.213.

8. Ibid., p.182, 183.

9. Ibid., p.218.

10. Ibid., p.203.

11. Ray Raphael, Founding Myths: Stories the Hide Our Patriotic Past, New York: The New Press, 2004, p.175.

12. Ibid., p.175-179.

13. Ibid. p.175-179. 